\title{
Case Study of Public-Private Partnership on Infrastructure Projects of Tibar Bay Port in Timor-Leste
}

\author{
Zeferino Soares Lopes, Fredy Kurniawan, Julistyana Tistogondo \\ Department of Civil Engineering, Faculty of Engineering, Narotama University, Indonesia \\ *Corresponding author E-mail: zeferinosoareslopes@gmail.com
}

Manuscript received 15 April 2021; revised 1 May 2021; accepted 15 June 2021. Date of publication 3 July 2021

\begin{abstract}
Public - Private Partnership (PPP) offers many potential benefits for the government in providing infrastructure facilities. However, the implementation of the Public Private Partnership project is not easy. Infrastructure Development is one of the development priorities in developed and developing countries, including Timor-Leste. As one of the priorities of national development, cost limitations are the main problem faced by the government. Therefore, to overcome the lack of funding, the government can involve the private sector in terms of providing funds to finance the construction of infrastructure facilities. The Government of the Democratic Republic of TimorLeste (RDTL) must have good regulations to achieve the goals of Timor-Leste in the future through cooperation between the government and the private sector. Good regulation is one of the best ways for good cooperation between the government and the private sector.In this study, the chosen location is the Tibar Bay Port in Timor-Leste. Based on the results of research that has been done, infrastructure development efforts do not have to rely on the Timor-Leste government as a single actor, the involvement of other parties such as the private sector is also needed for infrastructure development. The Government of Timor-Leste is fulfilling a big dream for the the future through the development of infrastructure in accordance with the strategic development plan for 2011-2030 to come, because the Government of Timor-Leste prepares a bright future for a country to become a developed country like other countries.
\end{abstract}

\section{Keywords: Strategic Development Plan, Public - Private Partnership (PPP), Infrastructure Development.}

\section{Introduction}

The Democratic Republic of Timor-Leste is the youngest country in the world, gaining independence in 2002. The government through an ambitious program to develop infrastructure in accordance with the 2011-2030 development plan is coming [1]. The base of the government's development strategy is to include the private sector to help diversify and grow the economy and create new opportunities for all East Timorese. Timor-Leste is rich on the coast oil and gas, with excellent fishing resources and tourism potential. In 2011, the Directorate-General for International Cooperation and Development (DevCo) was approached to help identify the important Public Private Partnership (PPP) projects together with the Asian Development Bank (ADB) [2], International Finance Corporation (IFC) works with the Government to refine a long list of projects, identify the most suitable to be submitted as a PPP and then develop preliminary business cases for the most feasible. The new port will have a transformative economic effect, eliminate congestion and allow for greater traffic and ships. This will provide better access and lower costs for imports and exports of goods, including trading in new markets. The port is also expected to be a destination for cruise ships, in line with Timor-Leste's tourism ambitions. Timor-Leste's future is brighter today thanks to the steps taken by the government to open up its economy and enable investment. One of the largest private investments in public infrastructure is the Port of Tibar Bay, the first Public Private Partnership or PPP project in the country of Timor-Leste [3]. The World Bank and International Finance Corporation (IFC) help build the capacity of Public Private Partnership, develop projects, and gain interest from international investors. The Port of Tibar Bay is now being built, the port can increase cargo capacity, improve the business climate, and help diversify the economy and create jobs for Timor-Leste.

The Port of Tibar Bay is located $10 \mathrm{~km}$ west of Dili and will replace the Port of Dili with sophisticated port facilities developed as the first PPP in Timor-Leste. The port will cost around US \$ 490 million to be built over the 30-year concession period, consisting of an initial investment of US \$280 million and a further US \$ 210 million in expansion costs as the port grows over time. In 2016 a competitive international tender facilitated by IFC was won by the Bolloré Group, which will contribute US $\$ 360$ million of this fee, and the remainder (US \$ 130 million) will be funded by the Government [2] [4].

So through the 2011-2030 Strategic Development Plan for Timor-Leste called for significant investment in infrastructure. To achieve this successfully, the government is considering a number of financing and implementation options. This includes the use of Public Private Partnership (PPP) to provide strategic infrastructure. The government has made it clear that to be adopted, PPPs will need to show the

Copyright $\odot$ Authors. This is an open access article distributed under the Creative Commons Attribution License, which permits unrestricted use, distribution, and reproduction in any medium, provided the original work is properly cited. 
overall benefits of society and be consistent with government plans and priorities. The project reached financial closure in 2018 and is expected to be operational by the end of 2021 [5] [6].

In accordance with the background outlined above, the research issues formulated to be assessed are as follows [7]:

1. How are the laws and regulations on Public Private Partnership (PPP) in Timor-Leste?

2. What factors that influence the success of PPP in Timor Leste?

How is PPP applied to the Tibar Bay Port Infrastructure project in Timor-Leste?

\section{Literature Review}

To support the research to be conducted, there are several previous studies that are available and relevant to this research. Previous research conducted by other parties can be used as input and assessment material related to this research.

\subsection{Port Infrastructure in Timor-Leste}

The Democratic Republic of Timor-Leste next referred to as Timor-Leste has just starded a period of economic development after undergoing recovery from the conflict in 1999 and achieved independence in 2002 [8]. The Dili Port, located in the capital, is the only international port in Timor-Leste, functioning as a terminal for ferries operating from RAEOA-ZEESM-Oecusse and the island of Atauro has been upgraded with the assistance of the Japan International Coperation Agency (JICA). However, the capacity of the Dili Port is almost saturated and port security is unsatisfactory and the port is centrally located in the city of Dili. Safety measures to meet the requirements of the International Convention for the Safety of Passenger at Sea (SOLAS) have not been fully enforced and ferry passenger traffic and container cargo are not separated. Lack of maintenance of infrastructure and inadequate channel depth are some of the concerns of the port in supporting economic activities. The International Finance Corporation (IFC) is assisting the Timor-Leste government in formulating a plan to develop a new port in Tibar to the west of Dili. The development of this new port will take 4-7 years before completion, although it is included in the national development plan. Therefore, planning and implementing actions to use the Dili Port today is very important. The port of Dili is supported by the Timor-Leste government itself through the Ministry of Public Works of the Ministry of Transportation and Telecommunications Ministério das Obras Públicas, Trasporte e Comunicações de Timor-Leste under the coordination of the National Director of Maritime Transportation Administração dos Portos de Timor-Leste (APORTIL).

\subsection{Public Private Partnerships (PPP)}

Since 1990, more and more countries have usedschemes Public Private Partnership (PPP). At present, the United Kingdom (UK) has surpassed other countries in the number of PPP projects implemented. Other developed countries such as Australia, Germany, Korrea, South Africa, France, Portugal and Spaynol are also increasingly active in implementing PPPs [5] [9].

\subsection{PPP Model}

1. Design-Build (DB) "Traditional Procurement": Private sector partners design and build infrastructure to meet the specifications of public sector partners, often at fixed prices. Public partners assume all risks associated with construction (the risk of delays, cost overruns) and related to the operation and maintenance of infrastructure.

2. Operation \& Maintenance Contract (O\&M): Private sector partners, under contract, operate publicly owned assets for a certain period of time. Public partners retain ownership of assets.

3. Build-Finance (BF) : The private sector finances and builds new infrastructure. Public partners retain ownership of assets.

4. Design-Build-Finance-Maintain (DBFM) : Private sector partners design, finance and build new infrastructure components and maintain them but do not operate on long-term leases. Private sector partners transfer infrastructure components to public sector partners when the lease period expires.

5. Design-Build-Finance-Maintain-Operate (DBFMO) : Private sector partners design, finance and build new infrastructure components and operate / maintain them on long-term leases. Private sector partners transfer infrastructure components to public sector partners when the lease period expires.

6. Concession : Private sector partners take full responsibility for the public sector for the provision of public services / infrastructure.

\subsection{PPP Legislation in Timor-Leste}

The laws and regulations are formulated as follows:

Specific Decree Law Number 43 of 2015 dated December 28, Legal Limits on Public Private Partnership (PPP) for the Port of Tibar. Decree of Law Number 8 Year 2014 dated March 19 Regulating the Legal Regime for Governmental Cooperation (PPP). Decree Number 2 of 2014 dated January 15, First Amendment of Shrimp-Shrimp Decree Number 42 of 2012 dated September 7 approved the Public-Private Partnership Legal Regime. Legal Decree No. 42 of 2012 dated 7 September Legal Regime of Public-Private Partnership Timor-Leste.

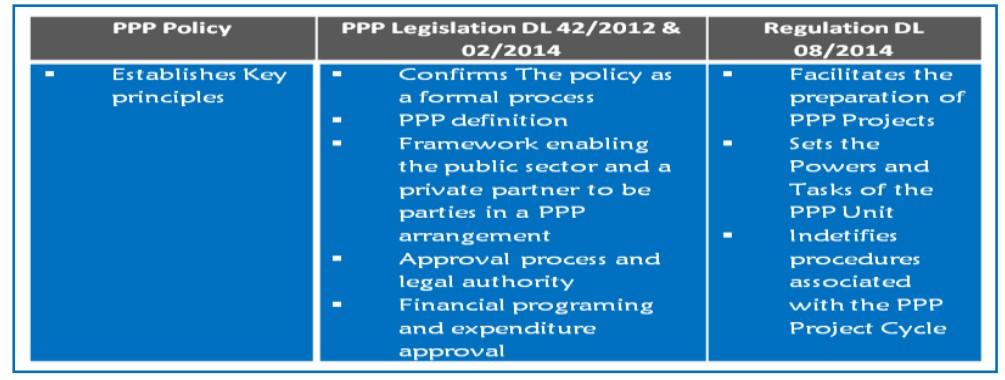

Fig 1. Timor-Leste's PPP-Policy, Legal Framework and Regulations Source: PPP Unit Minstry of Finance Timor-Leste 
The PPP market in India is not new but not as developed as in Western countries. The Indian government encourages the adoption of PPP as an option to meet the country's very high infrastructure needs. Some of the causes of the problems in PPP business in India include: Poor planning Unbalanced; Risk; Uncertainty uncertaintyuncertainty; Process group and Short-term political approach from government elites who want to show quick results for campaign material in the next general election [10].

Philippines has implemented theprogram Public Private Partnership as a good result because of the design philosophy of the country and because of practical needs. In 1986, the new domokarsi movement chose the president Aquino's administration, like several other Latin American countries, to deal with the problems of starting economic development with a huge foreign debt burden, bankruptcy and bureaucratic gridlock. As some Latin American countries have done, the Philippine government has privatized and deregulated as one of the main strategies to regulate and achieve economic recovery. Timor-Leste through the Timor-Leste Strategic Development Plan 2011 - 2030 calls for significant investment in infrastructure. To achieve this successfully, the government is considering a number of financing and implementation options. This includes the use of Public Private Partnership (PPP) to provide strategic infrastructure. Themodel Public Private Partnership will continue to promote the process of spending diversification to finance large investments [11].

The Government of Timor-Leste will identify projects in high-power sectors to create a variety of multiplication effects, and negotiate with investors to implement partnerships for investment. In this context the government must improve laws and regulations, as well as the competence of the PPP Unit in the Ministry of Finance to make good investment management. The Government of Timor-Leste negotiates with the Ministry of the private sector and manages projects and first builds large infrastructure projects such as the port of the Tibar Bay through the model Public Private Partnershi in Timor-Leste [12].

\section{Methods}

In this study the authors used the Case Study method. With the research flow chart as follows :

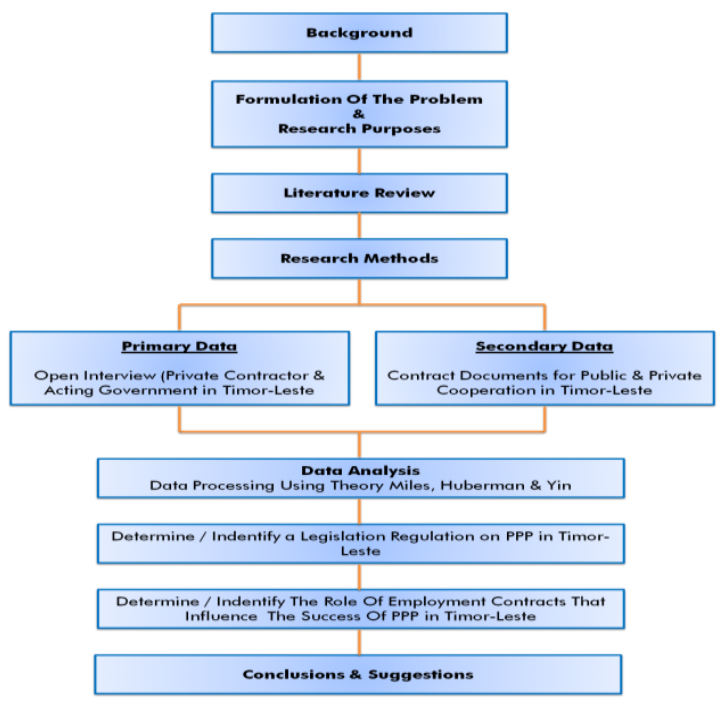

Fig 2. Research Diagram Flowchart

\section{Results and Discussion}

In analyzing the implementation of the issue of Public Private Partnership in the development of the infrastructure of the port of Tibar Bay, it must be identified in advance about the application of financing policies in the construction of the port regarding the problems any discussion that is experienced by the parties certain, namely the government as a regulator and entrepreneurs or investors as business people, and the community as the port collateral.

In this study, questionnaires were distributed to selected respondents who were relevant to this research material from the Public Private Partnership Unit and Project Management Unit involved in the infrastructure project of the Tibar Bay Port in Timor-Leste.

\subsection{Institutions involved in the PPP Project}

Table 1. Agencies involved in the PPP Project

\begin{tabular}{ccc}
\hline INSTITUTION TYPE & FREQUENCY & PERCENT (\%) \\
\hline $\begin{array}{c}\text { Public Private Partnership } \\
\text { Unit (PPPU) }\end{array}$ & 5 & $50 \%$ \\
$\begin{array}{c}\text { Project Management Unit } \\
\text { (PMU) }\end{array}$ & 5 & $50 \%$ \\
\hline TOTAL & 10 & $100 \%$ \\
\hline
\end{tabular}

Source : Data Processing Results 
Table 2. Position

\begin{tabular}{ccc}
\hline POSITION & FREQUENCY & PERCENT (\%) \\
\hline Director Project Management Unit For Tibar Bay Port & 1 & $10 \%$ \\
Economist \& Financial PPP Officer & 1 & $10 \%$ \\
Accoounting \& Finance Officer for PPP & 1 & $10 \%$ \\
National Environmental Specialist & 1 & $10 \%$ \\
Civil Engineer Assistant & 2 & $20 \%$ \\
Enviromental and Social Officer & 1 & $10 \%$ \\
National Infrastructur Engineer & 1 & $10 \%$ \\
Legal Officer & 1 & $10 \%$ \\
Staff & 1 & $10 \%$ \\
\hline TOTAL & 10 & $100 \%$ \\
\hline
\end{tabular}

Table 3. Level of Education

\begin{tabular}{ccc}
\hline LEVEL OF EDUCATION & FREQUENCY & PERCENT (\%) \\
\hline Bachelor Degree & 4 & $40 \%$ \\
Master Degree & 5 & $50 \%$ \\
Doctoral Degree & 1 & $10 \%$ \\
\hline TOTAL & 10 & $100 \%$ \\
\hline
\end{tabular}

Source : Data Processing Results

Table 4. Work Experience

\begin{tabular}{ccc}
\hline WORK EXPERIENCE & FREQUENCY & PERCENT $(\%)$ \\
\hline$<5$ Years & 9 & $90 \%$ \\
5-10 Years & 1 & $10 \%$ \\
\hline TOTAL & 10 & $100 \%$ \\
\hline
\end{tabular}

Source : Data Processing Results

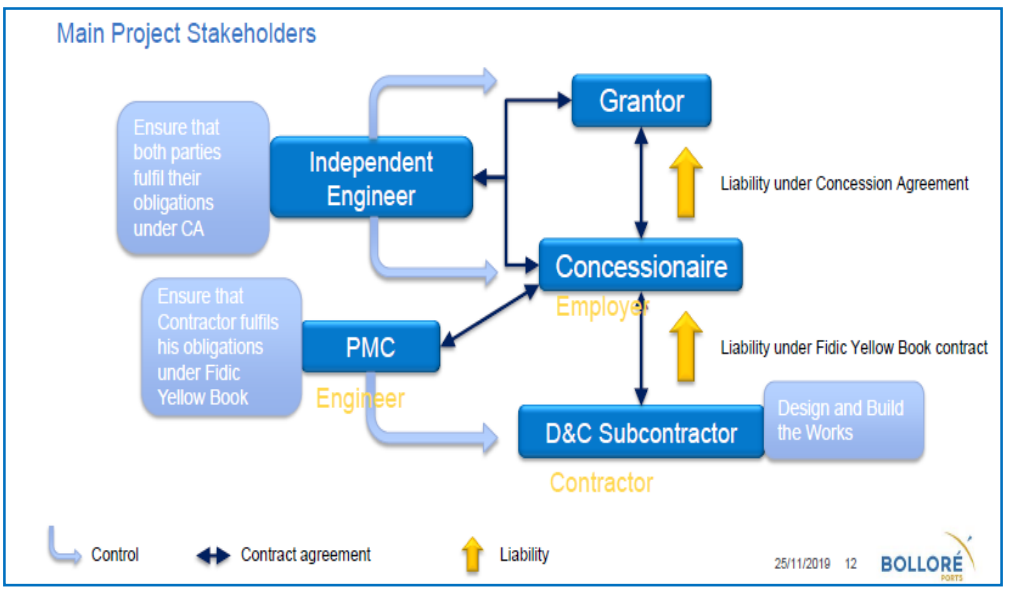

Fig 3. Project Organization

Source : Project Management Unit (PMU) Tibar Bay Port

\subsection{Description of Interview Results}

This research interview sheet is a collection of research indicators involved in the infrastructure project Public Private Partnership in Timor-Leste. In this study the method used is using a semi-structured interview method related to risk in Public Private Partnership (PPP) because the authors develop questions relatively about the topic taken on the Case Study of Public Private Partnership in the infrastructure project at the Tibar Bay Port in Timor- Leste.

From the results of interviews with income regarding PPP in infrastructure in Timor-Leste to respondents according to Mr. Junevio Antonio Silva Ximenes as Economist \& Financial PPP Officer, PPP in infrastructure in Timor-Leste it can be said that still in the initial stages of its implementation / implementation in Timor-Leste as one of the important strategies in allocating expertise and especially in terms of financing from the private sector in helping the Timor-Leste government develop infrastructure. PPP as a way to support the government and we look for the private sector how not only to fund investment but they have experience in the international and professional world can support us in strategic projects and infrastructure development in accordance with the Strategic Development Plan 2011 -2030 "Many projects but we are more priority to the Port of the Tibar Bay project and I see it running smoothly until it gets an award for Best Project of the Year of 2018 in the Asia-Pacific region".

According to Ms. Rosalyn Fernandes as the National Environmental Specialist for PPP Unit, it states that PPP to provide infrastructure in the country, in my opinion, the PPP model is good, more important about PPP, everyone must understand that PPP is actually a service profile, so the service profession. In PPP there is usually also a component about construction for physical projects that must be based on 
a proper feasibility study. Example of the Tibar port project: Tibar port has a maritime transportation infrastructure profession related to ports.

a. We should have a Dili Port, but we know that the Dili Port is old, has insufficient capacity, and is located in the city. So we need to build a modern port and a pretty good port capacity.

b. If we build with the PPP model is good or not? Because there are other alternative models that we use through others "traditional procurement". Traditional procurement is the usual supply of structures. So through the government issuing tenders for tendering with contractors to undergo construction. Not a contract to undergo construction alone but should be for the selection and operation of the port inside as well as a package for construction, in the construction of the port. The first thing is we have to go through a feasibility study before going to tender. In my opinion the PPP model is very good but it is not the way for all infrastructure that is used with the PPP model.

From Rui Soares, Head of Project Management Unit (PMU), PPP it is good not only for the government to establish but there is cooperation with the private sector. Once there is a financial aspect, reduced spending then from the technical aspect can also develop modern technology transference. PPP is a good infrastructure investment model. It encourages foreign direct investment and job transfer opportunities for creater from knowledge skills to local workers. In terms of, the private sector is a local company, it motivates local companies to play a large role in managing public infrastructure.

From the interviews of certain parties regarding the implementation of PPP in the infrastructure in comparison with the results of research that the author is more or less inspired and referenced from previous studies or previous studies relating to the background of trading problems in this thesis. The following previous studies related to this thesis include the First Research conducted by Kahyaogullari, 2013, Afyon Kocatepe University, "Public-Private Partnerships In Developing And Developed Countries: The Uk And Turkish Cases" This study sets out to determine whether the adoption process and the implementation of PPP policies differs between developing countries and developed countries. Then using this template, Turkey, as a developing country, and the United Kingdom, as a developed country, are examined to establish relations between countries of the development level of a country and its PPP policies. The findings show that PPP policies in developing and developed countries differ in five aspects, namely: 1) How policies penetrate into the political agenda; 2) The government's goal of adopting a PPP policy; 3) Sectoral Distribution; 4) Form of PPP, and 5) Regulatory Framework.

The second research conducted by Kurniawan, and friends 2016, Narotama University Surabaya, "Case Study: Public Private Partnership Project in Wonokromo Market and Tambah Rejo Surabaya Market" This research aims to present the results of a case study on the implementation of Private Government Cooperation in Surabaya. From the results of a PPP case study in Surabaya, it can be concluded that: a) a feasibility study on a PPP project is crucial to the success in implementing a PPP project, and b) good governance is needed in managing PPP projects.

So from there Timor-Leste is a new country and is the easiest country in the Asian region to make diplomacy efforts with developed countries to help the development of their country. But the history of the conflict and its struggle for independence has left the country. Poor inheritance of infrastructure, limited economic development, and very low capacity because the country creates institutions in which its future will be built in accordance with the Timor-Leste Strategic Development Plan 2011 - 2030. PPP is a project concept newly introduced in Timor- Leste. Leste and the Port of the Tibar Bay project are new projects as part of the PPP. From a PPP point of view it can have the advantage of bringing large investors into the country and Timor-Leste can move forward like other developing countries.

\subsection{Analysis of Research Results}

The results of factor analysis are able to identify the main factors that are important for the delivery of PPP projects in the study area. The main factors identified for public sector participants are the focus of leadership, risk allocation and economic policy. The four main factors that are identified for private investors in implementing PPP projects are good socio-economic factors, good governance and political support, a short construction period, and providing good services needed by the public. These factors are considered the most important and also used, will improve the implementation of PPPs for infrastructure development in the country of Timor-Leste. Risk allocation is another factor that is considered important at the project planning stage and this helps allocate risk to parties to be better positioned to manage it. Also good economic policy from the government gives direction to public sector participants while the focus of public sector leadership helps the whole process in achieving the objectives of implementing the PPP project according to the 2011-2030 Strategic Development Plan for Timor-Leste to call for significant investment in infrastructure.

These factors are based on the analysis of the results of research on the focus of leadership, risk allocation and economic policy as the main factors to be implemented in the Public Private Partnership scheme in Timor-Leste. In the Timor-Leste context, specific matters that must be considered are: who will benefit from the PPP project, the company, the government or the community? What is the impact or benefit of the project on the lives of local communities?, How is the project maintenance and quality? Who will pay costs and revenues to fall substantially from projected? ; Is this project sustainable or not? ; Connecting whole economies, equality and justice? ; How to minimize corruption ?. Of these several factors are very important in managing the Public Private Partnership scheme. (Lao Hamutuk, 2018).

The focus of leadership as the main factor in Public Private Partnership, makes the difference in this research that the government does not focus on domestic infrastructure, it focuses more on each other's politics. Among factors such as political risk, lack of infrastructure and strong budget constraints, PPP is an attractive solution for the government, sometimes due to political delays, sometimes because of election motivation. However, with well developed laws and regulations to provide favorable government support for their development. The case of the Tibar Bay Port infrastructure in Timor-Leste reveals an inability to build political commitment and demonstrate the assessment of a technically competent public entity.

According to Daniel (2018), "focus" is very important in our personal and professional lives today. There are so many things that can interfere with our attention to priority matters, so that awareness of "focus" deserves attention. Focus is paramount in whatever we do. The better we focus our attention on something, the better the results we get. This also applies in the field of leadership.

However, the successful implementation of public private partnerships in other countries of the world provides important lessons so that their governance is always considered best practice and receives several recommendations from academics, local communities, civil society, workers' practices and international agencies. The government has made it clear that in order to be adopted, PPPs will need to demonstrate the benefits of society as a whole and be consistent with government plans and priorities 


\section{Conclusion}

Based on the results of research and discussion that has been conducted by researchers regarding the implementation of the Public Private Partnesrship in Timor-Leste through infrastructure development Tibar Bay Port in Timor-Leste then look at several factors important to be successful PPP implementation then can researchers make conclusions in writing this, namely:

1. The relative importance index shows that the Government of Timor-Leste has a high level of readiness ("quite ready" to "very ready") for the implementation of scheme Public Private Partnership for infrastructure provision in the Democratic Republic of Timor-Leste especially in the aspect of commitment and coordination institutional.

2. The Port of the Tibar Infrastructure Project with the new port will have a transformative economic effect, new implementation will begin through the Public Private Partnership scheme in Timor-Leste the project is "on going". The Government's experience and lengthy learning still needs to be done, such as in the field of improving good practice and standardizing contracts and procedures. Positive evaluations in recent years, however, have proven to be a hope for better use of the Public Privaate Partnership in TimorLeste.

3. Research looks at several important factors for the successful implementation of the Public Private Partnership. Among factors such as political risk, lack of infrastructure and with strong budget constraints, PPP is an attractive solution for the government, sometimes due to political delay, sometimes due to election motivation. However, laws and regulations are well developed to provide favorable government support for their development. The case of the Tibar Bay Port infrastructure in Timor-Leste reveals the inability to build political commitment and demonstrate the judgment of technically competent public entities.

4. Timor-Leste is not ready to open social work for the private sector if the government does not have the capacity to manage good companies, it can deal with major problems in the future. From there if we say to allow private companies from abroad to undergo project systems such as roads, electricity, clean water etc., from there the government cannot manage the capacity of the system well to provide work for the private sector for future investment.

Participants from the public and private sectors can be given better information on factors that might help in the delivery and implementation of PPP projects in Timor-Leste.

\section{References}

[1] N. M. Susilawathi et al., "Neurocysticercosis cases identified at Sanglah Hospital, Bali, Indonesia from 2014 to 2018 ," Acta Trop., vol. 201, 2020, doi: 10.1016/j.actatropica.2019.105208.

[2] “Analisis Bibliometrik Manajemen Risiko Konstruksi : 2005-2015,” J. Tek. Sipil, 2016, doi: 10.5614/jts.2016.23.3.8.

[3] R. M. Schomaker, "Conceptualizing Corruption in Public Private Partnerships," Public Organ. Rev., vol. 20, no. 4, 2020, doi: 10.1007/s11115-020-00473-6.

[4] W. S. \& $\quad$ K. Wong et al., “No 主観的健康感を中心とした在宅高齢者における 健康関連指標に関する共分散構造分析Title,”J. Pendidik. Malaysia, 2018.

[5] L. A. Parker, G. A. Zaragoza, and I. Hernández-Aguado, "Promoting population health with public-private partnerships: Where's the evidence?," BMC Public Health, vol. 19, no. 1, 2019, doi: 10.1186/s12889-019-7765-2.

[6] A. D. Bank, "Asian Development Bank and Cambodia: Fact Sheet," World Dev., no. December, 2011.

[7] J. Jia and R. Subasinghe, "Colombo Declaration: Strengthens Regional Cooperation in Aquaculture Development," FAO Aquac. Newsl., no. 48, 2011.

[8] N. Bankes, "Settling the maritime boundaries between Timor-Leste and Australia in the Timor Sea," J. World Energy Law Bus., vol. 11, no. 5, 2018, doi: 10.1093/jwelb/jwy021.

[9] J. Braz, "Public-Private Partnerships in Development: Three Applications in Timor Leste," World, vol. 221, no. $221,2003$.

[10] J. K. Roehrich, M. A. Lewis, and G. George, "Are public-private partnerships a healthy option? A systematic literature review," Soc. Sci. Med., vol. 113, 2014, doi: 10.1016/j.socscimed.2014.03.037.

[11] H. Wang, W. Xiong, G. Wu, and D. Zhu, "Public-private partnership in Public Administration discipline: a literature review," Public Manag. Rev., vol. 20, no. 2, 2018, doi: 10.1080/14719037.2017.1313445.

[12] J. Ramke et al., "A public-private partnership to provide spectacles for Timor-Leste," Community Eye Health Journal, vol. 20, no. 63. 2007. 